UDC 378.046:811.1/.9

DOI https://doi.org/10.31392/NPU-nc.series5.2020.77.18

Dubinina N. $V$.

\title{
THE DIFFICULTY OF THE TRANSITION FROM THE ENTRANCE EXAM TO THE EXTERNAL EXAMINATION
}

The article is devoted to the problem of holding the external independent testing (in foreign languages) for future Masters in Ukraine, which has become the necessity in connection with the increase of the demands to the quality of modern higher education.

Today education is one of the most important factors in the sustainable development of society, competitiveness and national security of the state. Socio-economic reality requires from the vocational education system such specialists, who could immediately, without an adaptation period, be able to qualitatively fulfill specific professional duties. The quality of education is becoming a fundamental category of state policy all over the world, the main reference point of international policy in the field of education of UNESCO, the United Nations, and the European Union. In the Bologna process, aimed at creating a common European system of higher education, the quality problems of higher education occupy a major place.

The urgency of the problem of conducting external independent evaluation for future masters is due to the unsatisfactory state of training of modern professionals to carry out future professional activities, taking into account the new requirements.

As it is known, currently in Ukraine there are more universities than in any other country of the EU, and accordingly, Ukraine has the largest number of specialists with higher education. But does this testify the quality of education of its graduates, who are able to perform professional tasks, using new technologies that are constantly changing and improving? According to the statistics, today the educational level of modern professionals is not satisfactory and needs changes and improvement.

The above-mentioned forced the Ministry of Education and Science to review and reform the content of higher education. One of the steps to fulfill this task was the introduction of bachelor's graduates to take independent tests for further admission to the master's degree. These are the only professional entrance test (OPET) and the only entrance exam (OEE). The only professional entrance test includes the testing of profiling disciplines. The only entrance exam is a test in a foreign language (English, German, French or Spanish, etc. - according to your choice).

If the introduction of external independent assessment of profile components to identify the real level of knowledge, skills, abilities of future masters in order to improve them in the future is quite understandable, then the question arises: why is it necessary to test foreign language skills in order to enter the Master course? Further we will prove the necessity of the external independent testing introduction, its effectiveness, and reveal its role in the educational process of a high school.

Key words: multimedia technologies, students, Masters, Bachelors, introduction, training, education, external independent evaluation, higher educational establishment.

In times of transition and economic crisis of the 1990s and early 2000s, public higher education budgets were radically cut; faculty's salaries decreased below the subsistence level; and wage delays were commonplace. Informal payments and duties compensated the absence of formal funding and became institutionalized at many universities. At certain prestigious institutions, bribes up to $\$ 10,000$ were demanded for admission, adding up to an annual admission corruption volume of approximately $\$ 200$ million. As the selection of new 2 students became increasingly based on money, instead of merit, even middleclass families could not afford to send their children to high-quality universities. Each university had its own admission procedure. Mostly these were nontransparent oral tests that were prone to corruption. In 2008, the Western orientated and reform-minded Viktor Yushchenko government introduced an independent assessment and admission system, similar to the American Scholastic Aptitude Test. The Ukrainian Center for Educational Quality Assessment was established to develop and control the new testing. It introduced a written standardized test that puts the students under same conditions and reduces opportunities for corruption. In contrast to other postcommunist countries, where analogous reforms seem to have failed, the EIT was successfully implemented. For example, in Russia only 16 percent of the population believe that the Unified State Exam (EGE) has reduced admission corruption. Experts as well as the society regard it as the most effective educational reform, since Ukraine's independence. This is remarkable, since the political context after the Orange Revolution was dominated by instability and standstill; but the reform has been carried out carefully and was backed by a broad coalition of then President Yushchenko, the Education Ministry, the international donor community, and domestic civil society [7].

The external independent testing is a complex of organizing procedures, directed to the identification of educational achievements' level of secondary and high school graduates.

The purpose of the external independent testing is the improvement of the educational level among the population of the country, and the realization of citizens' constitutional rights for the equal access to high education and Master degree obtaining, the fulfillment of the control for the State standard sticking of secondary and high education, and analyzing of the educational system state, the forecasting of its development.

The results of the external independent testing are considered to be the results of the State attestation and the entrance exams to the higher educational establishments and for Master degree obtaining.

The system of the external independent testing is being formed in Ukraine by the support of the international and public organizations. 
The provision of the external independent testing is being made by the Ukrainian centre of educational quality assessment, by the mutual work of the local bodies of education management, the regions' institutes of post-diploma pedagogical education, and educational institutions.

The improvement of the external independent testing has given good results in the improvement of the secondary and high education quality in Ukraine, influenced the general educational level positively and became an important factor in the fight with corruption.

The external independent evaluation or External independent testing (EIT, external testing, ET) are examinations for admission to universities of Ukraine. Complex organizational procedures (first - testing) aims to determine the level of academic performance of secondary schools during their admission to higher education. The purpose of external evaluation: improving public education and implementation of Ukraine's constitutional rights to equal access to quality education, monitoring of compliance with the State Standard of secondary education and the analysis of the educational system, predict its development. The results of external testing are considered to be a state of final attestation and the results of entrance examinations to higher educational institutions. The provision of external evaluation was carried out by the Ukrainian Centre for Educational Quality Assessment in partnership with local education authorities, Regional Institute of Postgraduate Education, educational institutions.

During the last educational years (2018-2020) the introduction of the external independent testing in foreign languages caused much displeasure from both teachers and students. The main reasons for this dissatisfaction are the following: if, in accordance with the Constitution of Ukraine, the state language is Ukrainian why is it necessary to pass the test in foreign language? Foreign languages are not required in the work of Ukrainian specialists of different branches of knowledge, and all documentation is in Ukrainian language, including international treaties and instruments, which are ratified by Ukraine. Currently our state cannot provide the process of foreign languages teaching, necessary for passing the Bachelor exam (only 1-2 years), but it requires its knowledge. First of all, this is due to the small number of teaching hours, devoted to foreign language learning. And, if we take into account the fact that at all the universities' students are taught a foreign language in their specialty, how will they prepare for the external independent testing in the general course?

The change of threshold score. If before the level of B1 was enough to pass the exam, now the level of B2 is necessary.

In order to eliminate the above-mentioned contradictions and prove the relevance and necessity of knowledge of a foreign language, and the passing of external independent testing in it, it should be noted that Ukraine cooperates with many EU countries nowadays. Thus, there is a need for the ability to negotiate with foreign partners on professional and domestic topics. All this requires a good vocabulary, lexical and grammatical skills, skills to carry on a conversation (communication skills) and the lack of "verbal communication". Taking into account all the above-mentioned, the following tasks in a foreign language were developed:

Part "Reading". The purpose of the part "Reading" is to identify the level of formation of independent reading and understanding of authentic texts over a period of time by future Masters. The successful completion of this task does not imply knowledge of absolutely all lexical and grammatical units, idioms, and requires only understanding of the text content as a whole, the ability to separate the odd and unnecessary information, the ability to generalize the content of the given text and to come to conclusions. Therefore, part of the "Reading" includes the following tasks:

- choose a title for each paragraph of the text;

- continue the sentence according to the content of the text, choosing the correct answer;

- determine whether the statement is true or not in terms of the content of what is read;

- answer the question by selecting rules nu response to the proposed etc.

Part "the use of language", according to both teachers and students, is the most difficult "challenge" of testing. This is because each task has several answer options, and requires analysis of each word or expression. For example, you need to choose from a synonymous series a word that fits the meaning of the sentence - this means that the student must be able to distinguish the meaning of synonymous words; or in the task there is a coincidence of lexical form (it is necessary to choose, for example, an adjective or an adverb), stable expressions (idioms), etc. It is also mandatory to have the skills of using grammar (orientation in grammatical tenses of active and passive state, degrees of comparison of adjectives and adverbs, the use of prepositions, conjunctions, knowledge of impersonal verb forms (infinitive, gerund and adjective), phrasal and modal verbs, etc. In view of the above-mentioned, the following tasks have been developed for this part:

- supplement the text with the phrases suggested below;

- choose the correct answer (task to identify the level of knowledge of grammar).

Part "Listening" has no less difficulties than the "use of language". Among them are the following: unsatisfactory recording quality, slurred pronunciation of native speakers, low volume. During the previous years, listening caused a lot of outrage from students' side, but understanding native speakers, their pronunciation, different types of accents, intonation is an important component of foreign language proficiency. The ability to listen and understand is just as important as speaking and writing. Listening includes the following tasks: choose the correct answer to the question, insert the missing information on the content or correct incorrect information, etc.

Part "Writing". The ability to write a letter, an announcement, a complaint, a review for an article, a protocol, a report, a questionnaire, an application form, etc. are necessary in present conditions in connection with different 
situations at work and in life, which solution requires their correct and full description, and expressing your opinion about them.

These skills testify students' abilities to act in this or that situation.

The detailed consideration of the problem of implementation of external evaluation for admission to the master's degree allowed to identify the following reasons for its introduction:

- qualitative students' motivation for the classroom, independent and individual work during their education;

- the creation of equal conditions for all bachelors that guarantees the real mobility inside the country;

- giving of analytical information about the quality of higher education and training in some universities that can be used in management decisions.

Furthermore, you can not ignore the complexity of the external evaluation during admission to the master's degree:

- as you know, at higher educational establishments, students study a foreign language in a professional direction - this means that they acquire knowledge and skills to use professional vocabulary, which is developed throughout the study (texts, dialogues, grammar tasks), and have to pass the external examination in general course;

- insufficient level of language proficiency due to lack of teaching hours;

- lack of experience in communication with native speakers;

- inconsistency of the program of universities and tasks of external evaluation.

Conclusions. In view of the above-mentioned, we think, it is necessary to learn a foreign language in all the universities within 4 years of training twice a week (one lesson in a foreign language for the professional purpose, and the second - for general course) with the use of new multimedia technologies, and the creation of the courses for external testing preparation on the basis of higher education, conducting students exchange programs in order to gain experience in communicating with native speakers on both social and professional topics.

Such conditions will ensure the appropriate level of knowledge of graduates and the successful completion of external independent testing, as well as their awareness of the need for knowledge of a foreign language and its application in educational and future professional activities.

Having looked through the structure of the external independent evaluation, we have come to such conclusions: in our higher educational establishments there is a lack of educational hours, assigned for foreign language' learning. It can lead to the bad preparation of our bachelors for the tests. In view of this, it is necessary to start the courses in the preparation of our students for the external independent evaluation in different foreign languages.

What concerns the future of the external independent testing, we consider that it will really encourage future Masters to learn foreign languages, both special and general course, in order to be able to communicate on different topics (public and professional) and with all the people all over the world. Because, as we know, foreign language knowledge is a part of professional competence of every person. In addition to it, foreign language knowledge reveals the opportunities to work in any country. We would like to see our future specialists perspective, successful and demanded on the international labor market.

\section{Bibliography:}

1. Англійська мова. Типові тестові завдання / С. В. Мясоєдова. Київ : Літера ЛТД, 2020. 120 с.

2. Англійська мова. Комплексне видання / О. Р. Валігура, Л. М. Давиденко. Тернопіль : Підручники і посібники, 2020. 544 с.

3. Зовнішнє незалежне оцінювання навчальних досягнень випускників загальноосвітніх навчальних закладів України, 2007.: Ін. форм. зб. Київ, 2007.

4. Зовнішне незалежне оцінювання навчальних досягнень випускників загальноосвітніх навчальних закладів. 2008 р. : Інформаційні матеріали / Український центр оцінювання якості освіти / Уклад. : І. Л. Лікарчук (наук. ред.) та ін. Київ, 2007. $288 \mathrm{c}$

5. Німецька мова. Комплексна підготовка до ЗНО / І. В. Гріцюк. Тернопіль : Підручники і посібники, 2019. 368 с.

6. www.OSVITA.ua.

7. Eduard Klein. Ukraine's external independent testing innovation. International higher education. 2014. Number 75. P. 24-25.

\section{References:}

1. Myasoidova S. V. (2020). Angliyska mova. Tipovi testovi zavdannya [English.Typical tests]. Kyiv: Litera LTD [Litera LTD].

2. Valigura O. R., Davidenko L. M. (2020). Angliyska mova. Kompleksne vidannya [English. Complex edition]. Ternopil: Pidruchniki i posibniki [Textbooks and manuals].

3. Zovnishnye nezalezhne otsinuvannya akademichnih dosyagnen vipusknikiv serednih shkil Ukraini. (2007). [The external independent assessment of academical achievements of Ukraine's secondary school graduates]. Kyiv: In. form. Zb. [In. form. Collection].

4. Likarchuk I. L. (2008). Zovnishnye nezalezhne otsinuvannya akademichnih dosyagnen vipusknikiv serednih shkil Ukraini. [External independent assessment of academical achievements of Ukraine's secondary school graduates]. Informatsiyni materiali / Ukrainskiy tsentr otsinuvannya yakosti osviti [Informational materials / Ukrainian centre of education quality assessment]. Kyiv: Naukova redaktsia. [Scientific reduction].

5. Gritsyk I. V. (2019). Nimetska mova. Kompleksna pidgotovka do zovnishnyogo nezalezhnogo otsinuvannya [German. Complex preparation to the external independent testing]. Ternopil: Pidruchniki ta posibniki [Textbooks and manuals].

6. Www.OSVITA.ua.

7. Eduard Klein. (2014) Innovatsii zovnishnyogo nezalezhnogo testuvannyia v Ukraini [Ukraine’s external independent testing innovation] / Mizhnarodna vishcha osvita [International higher education]. Number 75. P. 24-25. 


\section{Дубініна Н. В. Складність переходу від вступного іспиту до ЗНО}

Статтю присвячено проблемі впровадження та проведення зовнішнього незалежного тестування студентів з іноземної мови для вступу до магістратури. Описано реальний стан проблеми навчання іноземної мови у 3 ВО, розкрито причини, а також доведено необхідність та ефективність його впровадження в програму сучасної вищої освіти. Актуальність проблеми проведення зовнішнього незалежного оиінювання для майбутніх магістрів зумовлена незадовільним станом підготовки сучасних фахівиів до здійснення майбутньої професійної діяльності з врахуванням нових вимог.

Як відомо, нині в Украӥні нараховується більше вишів, ніж у будь-якій іншій краӥні ЄС, $і$, відповідно, вона має найбільшу кількість фахівців із вищэою освітою. Та чи говорить ие про якість освіти ї̈ випускників, здатних виконувати професійні завдання з використанням нових технологій, які постійно змінюються та вдосконалюються? Як стверджує статистика, сьогоднішній рівень підготовки сучасних фахівиів не є задовільним і потребує змін $і$ вдосконалення.

Вищезазначене змусило МОН переглянути та реформувати зміст вищої освіти. Одним із кроків до виконання иььго завдання стало запровадження випускниками бакалаврату складання тестів під час подальшого вступу до магістратури. Це Єдине фахове вступне випробування (СФВВ) та Єдиний вступний іспит (СВI). СФВВ передбачає виконання тестів із профільних дисциплін, $С B I-$ це тестування з іноземної мови (англійської, німецької, французької або іспанської на вибір).

Якщо запровадження зовнішнього незалежного оцінювання з профільних компонентів для виявлення реального рівня знань, вмінь, навичок $і$ здібностей майбутніх магістрів із метою їх вдосконалення в майбутньому є иілком зрозумілим, то виникає питання: навіщо для вступу до магістратури необхідно складати тест із виявлення рівня знань з іноземної мови?

Метою зовнішнього незалежного оцінювання $\epsilon$ : поліпшення рівня суспільної освіти та реалізація конституційних прав Украӥни на забезпечення рівного доступу до якості освіти, моніторинг дотримання державного стандарту середньої та вищої освіти й аналіз системи освіти, передбачення ї̈ розвитку. Результати зовнішнього незалежного оиінювання вважаються державною атестацією та результатами вступних випробувань до вищих навчальних закладів. Запровадження ЗНО проводиться Украӥнським центром оцінювання якості освіти у співпраці з місцевими органами освіти, регіональним інститутом вищої освіти, навчальними закладами. Система зовнішнього незалежного оиінювання формується в Україні за підтримки міжнародних і суспільних організацій.

Нині Україна співпраџює з багатьма краӥнами ЄС. Відповідно, виникає потреба у вміннях вести переговори із зарубіжними партнерами на професійні та побутові теми. Саме це вимагає належного словникового запасу, лексикограматичних навичок, вмінь вести бесіду (комунікативних навичок) та відсутності “мовленнєвого бар 'єру”.

Зважаючи на вищезазначене, вважаємо за необхідне вивчення іноземної мови у всіх вишах протягом чотирьох років навчання двічі на тиждень (одне заняття з іноземної мови за професійним спрямуванням, а друге - із загального курсу) з використання нових мультимедійних технологій, а також створення курсів для підготовки до 3 НО на базі вищого навчального закладу, проведення програм з обміну студентів із метою набуття досвіду спілкування з носіями мови як на суспільно-побутові, так і на професійні теми.

Ключові слова: мультимедійні технології, студенти, магістри, бакалаври, впровадження, підготовка, освіта, зовнішнє незалежне оцінювання, вищий навчальний заклад. 